\title{
Study on Compressive Strength of Sarmayam Clay Stabilized with Cement and Polypropylene Fiber
}

\author{
Suyadi $^{1}$, Hairulla ${ }^{2}$, Philipus Betaubun ${ }^{3}$, Agustan $^{4}$, Dina Pasalolo $^{5}$ \\ Civil Engineering Department \\ Universitas Musamus \\ Merauke, Indonesia \\ ${ }^{1}$ suyadi@unmus.ac.id, ${ }^{2}$ hairulla@unmus.ac.id, ${ }^{3}$ philipus@unmus.ac.id, ${ }^{4}$ agustan@unmus.ac.id, ${ }^{5}$ dinapasalolo@unmus.ac.id
}

\begin{abstract}
Land is the place where a structure or construction is established, both construction of buildings and roads. What often causes problems is if the soil has bad properties such as high plasticity and a large potential for shrinkage. One way to improve the shrinkage properties is to stabilize the soil with added cement and fiber to determine the dynamic compressive strength of subgrade in the form of clay and the effect of dynamic compressive strength of clay to the addition of cement and fiber. Clay mixed with cement and fiber was tested by dynamic compressive strength test using the SNI 03-6887-2002 method. The percentage addition of cement, cement and fiber is $5 \%, 10 \%$, and $15 \%$. Addition of fiber is $1 \%$ by weight of the cement used for each variation. The value of the dynamic compressive strength of the subgrade is $1,080 \mathrm{~kg} / \mathrm{cm} 2$. The value of dynamic compressive strength of clay stabilized with cement was $4.45 \mathrm{~kg} / \mathrm{cm} 2,7.77 \mathrm{~kg} / \mathrm{cm} 2,9.35 \mathrm{~kg} / \mathrm{cm} 2$. Cement and fiber are $3.86 \mathrm{~kg} / \mathrm{cm} 2,6.06 \mathrm{~kg} / \mathrm{cm} 2$ and $10.08 \mathrm{~kg} / \mathrm{cm} 2$. Soil mixed with cement is strong but brittle, with the addition of fiber, it can change the pattern of collapse that occurs, which is from patterns that behave in a brittle manner to patterns that behave in a ductile manner.
\end{abstract}

Keywords—Soil; Stabilization; Polypropylene

\section{INTRODUCTION}

Land, in the classification, can be in the form of gravel, sand, silt and clay which have different utilization and carrying capacity[1]. For land in the Merauke area, most of it is clay, which has sensitivity to changes in water content. Changes in water content in clay can cause building instability so that problems are often encountered in planning buildings if they have to construct a construction. The clay to be studied is in Sarmayam Indah Village, Tanah Miring District, Merauke Regency which is often used for landfill and is sometimes used for construction buildings.

\section{METHODS}

\section{A. Type of Research}

This type of research is experimental study. The test material studied was stabilized clay soil with added cement and fiber which aims to determine the dynamic compressive strength of subgrade in the form of clay and the effect of dynamic compressive strength of clay to the addition of cement and fiber.

\section{B. Mixing method}

Mixing ingredients used in testing. The soil material used in air dry conditions is then weighed in accordance with predetermined variations, $100 \%$ native soil $+0 \%$ cement and fiber, $95 \%$ native soil $+5 \%$ cement and fiber, $90 \%$ native soil $+10 \%$ cement and fiber, $85 \%$ native soil $+15 \%$ cement and fiber, $80 \%$ native soil $+20 \%$ cement and fiber. For the addition of fiber, $1 \%$ of each percentage of cement weight varied[2]. The weighted soil is added with water according to the optimum water content obtained from previous compaction on each mixture, then stirred so that the water is evenly mixed and put into an airtight plastic bag so that the moisture content is maintained, taking care for 1 night to be homogeneous. Then give added materials according to the variations, mix and print[3].

\section{Testing Method}

The testing of the results of mixing the soil with cement and fiber is done after sample curing[4]. Curing time is very important because the strength of the mixture rises gradually with aging. The curing time in this study is 3 days, 7 days, and 14 days. Testing of dynamic compressive strength is to determine the increase in soil strength after the process of mixing the soil with cement and polypropylene fiber. This test method includes testing work to obtain compressive strength test specimens of soil mixtures with cement and polypropylene fiber moulded in cylinders with a ratio of height:diameter $=2: 1$ with a cylinder height of $9.5 \mathrm{~mm}$ and a diameter of $4.75 \mathrm{~mm}$, tested after the test object is cured. The compressive strength is the maximum pressure at the time of compressive strength testing until the sample of the specimen has collapsed. The dynamic compressive strength testing is based on SNI 03-6887-2002[5].

\section{RESULTS AND DISCUSSION}

\section{A. Soil Characteristics Test}

From the testing of soil characteristics, the result of moisture content of clay was $3.847 \%$ and the specific gravity was $2.654 \%$. Atterberg boundary testing with a liquid limit[6] of $67.411 \%$, a plastic limit of $34.348 \%$, and a plastic index of $33.062 \%$ were also carried out. The soil weight is $1.81 \mathrm{gr} / \mathrm{cm}^{3}$. Then compaction[7] was done to find the maximum dry weight and optimum moisture content, with dry content 
weight ( $\gamma \mathrm{d} \max )$ of $1.658 \mathrm{gr} / \mathrm{cm}^{3}$ and optimum water content (w optimum) of $19.69 \%$.

\section{TABLE I. RESULTS OF SOIL CHARACTERISTICS TESTING}

\begin{tabular}{|c|l|c|c|}
\hline \multirow{2}{*}{ No. } & \multicolumn{2}{|c|}{ Examiners } & \multicolumn{2}{c|}{ Examiner Results } \\
\cline { 2 - 4 } & Physical Characteristics: & 3.847 & $\%$ \\
\hline 1 & Moisture Content (w) & 2.657 & \\
\hline 2 & Gravity (Gs) & 67.411 & $\%$ \\
\hline 3 & Liquid Limit (LL) & 34.348 & $\%$ \\
\hline 4 & Plastic Limit (PL) & 33.062 & $\%$ \\
\hline 5 & Plastic Index (PL) & 1.810 & $\mathrm{gr} / \mathrm{cm}^{3}$ \\
\hline & Mechanical Properties: & 1.658 & $\mathrm{gr} / \mathrm{cm}^{3}$ \\
\hline 6 & Fill Weight & 19.69 & $\%$ \\
\hline 7 & Maximum Dry Fill Weight $(\gamma \mathrm{d}$ max) & \multicolumn{2}{|c|}{} \\
\hline 8 & Optimum Water Content (w Optimum) &
\end{tabular}

B. Dynamic compressive strength test [5]

1) Without mixture (100\% native soil + 0\% cement: The soil without a cement mixture is moulded by a cylindrical mold, pressed and tested for the dynamic compressive strength.

TABLE II. THE RESULTS OF DYNAMIC COMPRESSIVE STRENGTH TEST ON 100\% NATIVE SOIL

\begin{tabular}{|l|l|l|}
\hline No & Curing (days) & qu value $\left(\mathbf{k g} / \mathbf{c m}^{2}\right)$ \\
\hline 1 & 3 & 1.24 \\
\hline 2 & 7 & 1.35 \\
\hline 3 & 14 & 1.49 \\
\hline
\end{tabular}

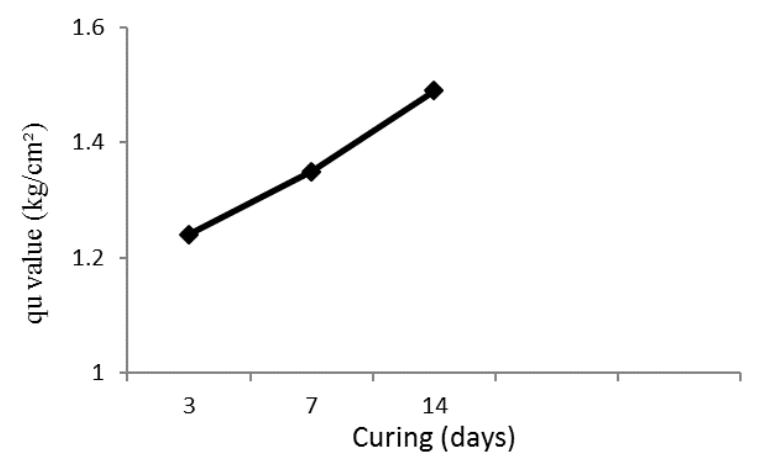

Fig. 1. Recapitulation graph of dynamic compressive strength test results on $100 \%$ native soil

2) Mixture of soil with cement: The soil which is added with optimum moisture content and cement, is moulded then tested according to the age of curing.
TABLE III. THE RECAPITULATION OF DYNAMIC COMPRESSIVE STRENGTH TEST RESULTS ON SOIL MIXED WITH CEMENT

\begin{tabular}{|c|c|c|c|c|}
\hline No & $\begin{array}{c}\text { Cement } \\
\text { content } \\
(\%)\end{array}$ & $\begin{array}{c}\text { 3 Day Cured } \\
\left(\mathbf{k g} / \mathbf{c m}^{\mathbf{2}}\right)\end{array}$ & $\begin{array}{c}\mathbf{7} \text { Day Cured } \\
\left(\mathbf{k g} / \mathbf{c m}^{\mathbf{2}}\right)\end{array}$ & $\begin{array}{c}\text { 14 Day Cured } \\
\left(\mathbf{k g} / \mathbf{c m}^{\mathbf{2}}\right)\end{array}$ \\
\hline 1 & 5 & 2.77 & 3.26 & 4.45 \\
\hline 2 & 10 & 4.97 & 6.14 & 7.77 \\
\hline 3 & 15 & 8.42 & 8.60 & 9.35 \\
\hline
\end{tabular}

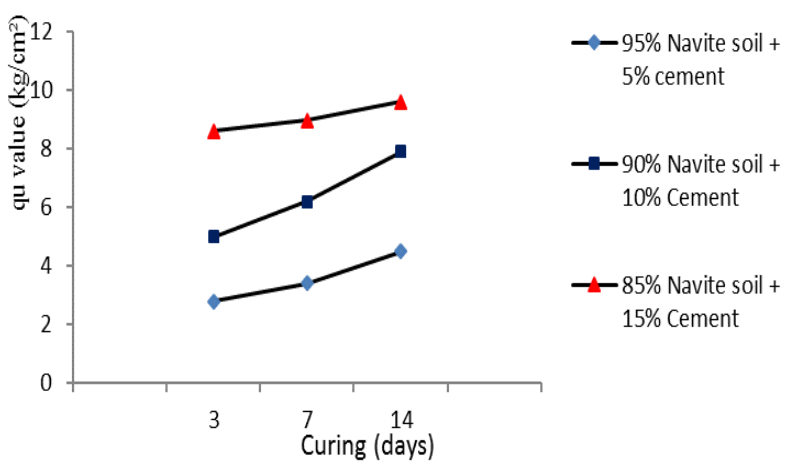

Fig. 2. Graph of the relationship between curing and dynamic compressive strength of soil with cement mixtures

3) Mixtures of soil, cement and fiber: The soil which is added with optimum moisture content is mixed with cement and fiber, then cured for 3 days, 7 days, 14 days and moulded on the days that have been determined and then tested with a pressure test instrument according to the age of curing. The results are shown in the following table.

TABLE IV. RECAPITULATION OF DYNAMIC COMPRESSIVE STRENGTH TEST RESULTS ON LAND, CEMENT AND FIBER MIXTURES

\begin{tabular}{|c|c|c|c|c|}
\hline No & $\begin{array}{c}\text { Cement and } \\
\text { fiber } \\
\text { content }(\%)\end{array}$ & $\begin{array}{c}\text { 3 Day Cured } \\
\left(\mathbf{k g} / \mathbf{c m}^{\mathbf{2}}\right)\end{array}$ & $\begin{array}{c}\mathbf{7} \text { Day Cured } \\
\left(\mathbf{k g} / \mathbf{c m}^{2}\right)\end{array}$ & $\begin{array}{c}\text { 14 Day } \\
\text { Cured } \\
\left(\mathbf{k g} / \mathbf{c m}^{\mathbf{2}}\right)\end{array}$ \\
\hline 1 & 5 & 2.72 & 3.60 & 3.86 \\
\hline 2 & 10 & 3.54 & 4.83 & 6.06 \\
\hline 3 & 15 & 4.27 & 5.33 & 10.08 \\
\hline
\end{tabular}

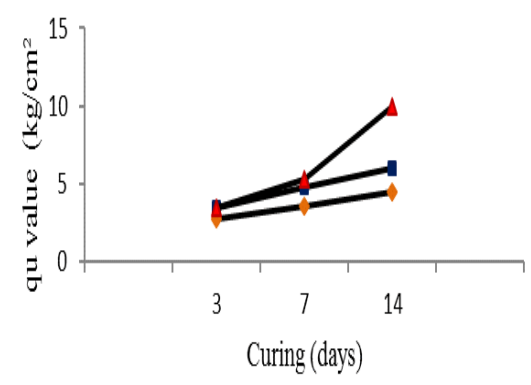

- $-95 \%$ Navite Soil + $5 \%$

Cement and Fiber

$-90 \%$ Navite Soil+ $10 \%$

Cement and Fiber

$-85 \%$ Navite Soil $+15 \%$

Cement and Fiber

Fig. 3. Graph of the relationship between curing and dynamic compressive strength of soil, cement and fiber mixtures 
From the test results, it was found that the dynamic compressive strength in $95 \%$ variation of native soil which was added by $5 \%$ cement and fiber experienced an increase. At 3 days curing, the value of the dynamic compressive strength is $2.72 \mathrm{~kg} / \mathrm{cm}^{2}$. Along with curing, the value increases. At 7 days curing, the dynamic compressive strength is $3.60 \mathrm{~kg} / \mathrm{cm}^{2}$, and at 14 days curing the value becomes $3.90 \mathrm{~kg} / \mathrm{cm}^{2}$. The increase in dynamic compressive strength occurs in all variations. In the variation of $90 \%$ native soil plus $10 \%$ cement and fiber, for 3 days curing, the value of dynamic compressive strength is $3.54 \mathrm{~kg} / \mathrm{cm}^{2}$, and for 7 days is $4.83 \mathrm{~kg} / \mathrm{cm}^{2}$, and then at 14 days curing, the dynamic compressive strength is $6.06 \mathrm{~kg} / \mathrm{cm}^{2}$. The same thing also happened in the variation of $85 \%$ of native soil which was added by $15 \%$ of cement and fiber. The increase is very significant. At 3 days curing, the value of dynamic compressive strength is $4.27 \mathrm{~kg} / \mathrm{cm}^{2}$, and then in the next test for 7 days curing, the dynamic compressive strength is 5.33 $\mathrm{kg} / \mathrm{cm}^{2}$, and at 14 days curing the dynamic compressive strength increased by $10.08 \mathrm{~kg} / \mathrm{cm} 2$.

\section{The effect of adding cement and fiber content to the value of dynamic compressive strength}

The results of dynamic compressive strength of 3 days curing soil were $2.80 \mathrm{~kg} / \mathrm{cm}^{2}$. At mixing of $5 \%, 10 \%, 15 \%$ cement content, there is an increase in the compressive strength value gradually at $130.83 \%, 314.17 \%, 601.67 \%$. The increase in the value of the dynamic compressive strength explains that the curing time for 3 days is enough to soil with cement to react. For the mixture of cement and fiber also increases but not as much as the soil mixture with cement only. The addition of 5\%, $10 \%, 15 \%$ cement and fiber content increase the compressive strength by $126.67 \%$, $195.00 \%, 255.83 \%$ of the compressive strength of the native soil for 3 days curing.

The result of the dynamic compressive strength test of 7 day cured native soil is $3.40 \mathrm{~kg} / \mathrm{cm}^{2}$. The values increase after the addition of $5 \%, 10 \%, 15 \%$ cement content, which are $143.28 \%, 210.45 \%, 541.79 \%$. For a mixture of soil, cement and fiber also increases. Addition of cement content of 5\%, $10 \%, 15 \%$ added to the value of dynamic compressive strength of $168.66 \%, 260.45 \%, 297.70 \%$.

The result of the dynamic compressive strength test of native soil at 14 days curing is $4.50 \mathrm{~kg} / \mathrm{cm}^{2}$, then added by cement content of $5 \%, 10 \%$, and $15 \%$, the compressive strength increased by $200.68 \%, 425.00 \%$, and $531.76 \%$. For the mixture of soil, cement and fiber, the compressive strength increased by $160.81 \%, 309.46 \%, 581.08 \%$ of the compressive strength tested for 3 days, 7 days, 14 days.

A significant increase in the value of dynamic compressive strength occurs in the soil mixture that has been mixed with cement in $85 \%$ native soil plus $15 \%$ cement. The addition of $15 \%$ cement causes the contact area between the soil and cement to get better, which also gives a greater bond. From the results of observations when testing the samples, the greater the percentage of cement content added to the soil also rises the value of the dynamic compressive strength. The soil samples tested gradually experience a significant increase until they reach the peak of the tension, and their strength decreases very rapidly when it passes through this phase. The soil properties will get more brittle as the addition of cement content in the soil mixture. In the mixture of soil, cement and fiber, the increase in the value of the compressive strength is not as large as when the soil is mixed with cement only. This can be caused by the fiber material being added to the soil and the cement is not reactive in binding to soil particles, but the fiber functions as reinforcing fibers in the soil and cement mixture so it is able to reduce the collapse that occurs in cement stabilized soil. After the value of the dynamic compressive strength on the native soil is being tested, the interval of 3 days, 7 days and 14 days curing gives a very small value. This is because the condition of the native soil is very soft.

\section{CONCLUSION}

Based on the results of the research and discussion, it can be concluded that:

1. The value of compressive strength using Sarmayam clay: Subgrade on the road of Sarmayam Indah Village - Tanah Miring District is clay because according to AASHTO it is included in group A-7-5, and according to Unified it is included in the $\mathrm{CH}$ group that is inorganic clay with high plasticity of fat clay. The dynamic compressive strength value of clay before it is stabilized is $1071 \mathrm{~kg} / \mathrm{cm}^{2}$.

2. The value of dynamic compressive strength of the soil with cement and after it is stabilized with cement, and the addition of polypropylene fiber:

a. $5 \%, 10 \%$, and $15 \%$, the maximum dynamic compressive strength are $4.45 \mathrm{~kg} / \mathrm{cm}^{2}, 7.77 \mathrm{~kg} / \mathrm{cm}^{2}$, and $9.35 \mathrm{~kg} / \mathrm{cm}^{2}$.

b. For the addition of $5 \%, 10 \%$, and $15 \%$, the cement and fiber content of the maximum dynamic compressive strength are $3.86 \mathrm{~kg} / \mathrm{cm}^{2}, 6.06 \mathrm{~kg} / \mathrm{cm}^{2}$ and 10.08 $\mathrm{kg} / \mathrm{cm}^{2}$.

The clay which is stabilized with cement and fiber can significantly affect the value of dynamic compressive strength. A mixture of $15 \%$ cement of $9.35 \mathrm{~kg} / \mathrm{cm}^{2}$. The most significant increase occurrs in the mixture of $15 \%$ cement and fiber by $10.08 \mathrm{~kg} / \mathrm{cm}^{2}$. The mixture of soil, cement and fiber has a high dynamic compressive strength but it is brittle. The addition of fiber can change the pattern of collapse that occurs, which is from patterns that behave in a brittle manner to patterns that behave in a ductile manner that can reduce cracks and collapse.

\section{ACKNOWLEDGMENT}

We thank Universitas Musamus for facilities, supports, and publications

\section{REFERENCES}

[1] C. Hary and Hardiyatmo, Soil Mechanics 1, $4^{\text {th }}$ Ed., Yogyakarta, 2006

[2] Suyadi, N. Dewi S., and S. Yulius k., "Experimental Study of Compressive Strength of Clay-Free Soil Stabilized with Cement and Fiber Fiber," Mustek Anim Ha, vol. 5, no. 3, pp. 209-220, 2016.

[3] SNI and 03-3438-1994, "Procedures for Making a Plan for Stabilizing 
Soil with Portland Cement for Roads," pp. 36-38, 1994.

[4] E. Suardi, "Strong Pressure Study Of Soil-Free Clay With Aditive Cement and Cretaceous," J. Ilm. Poli Rekayasa, vol. 1, no. 1, pp. 9-18, 2005.

[5] SNI and 03-6887-2002, "Test Method for Compressive Strength of Soil Cement Mixture," pp. 1-8, 2002.

[6] SNI and 03-1967-1990, "Liquid Boundary Testing Method with the
Casagrande Tool," pp. 8-11, 1990.

[7] SNI and 03-1742-1989, "Method of testing light density for soil," pp. $1-9,1989$. 